\title{
Prospects of development of the transnational transport corridor of the northern sea route based on Sabetta sea port
}

\author{
N. A. Vukovic ${ }^{1,3} \bowtie$, Zh. A. Mingaleva ${ }^{2}$, A. V. Mekhrentsev ${ }^{3}$ \\ ${ }^{1}$ Saint-Petersburg State Forest Technical University, Saint-Petersburg, Russia; e-mail: shpak17121978@gmail.com \\ ${ }^{2}$ Perm National Research Polytechnic University, Perm, Russia \\ ${ }^{3}$ Ural State Forest Engineering University, Ekaterinburg, Russia
}

\begin{abstract}
The Northern Sea Route (NSR) and the opportunities it offers for international transportation networks is widely discussed not only in academic literature but also by the wider public. The purpose of this article is to analyze the economic and logistical prerequisites for the development of the NSR-based project, its opportunities and threats in the light of Russia's regional development. The article also focuses on the potential of the sea port of Sabetta, which may be turned into a transnational transport hub. The possibility of development of intermodal terminals is also discussed. The project presented in this article is based on the multimodal transport approach. The methodological framework relies on the method of branches, arbitrary variation in network programming, and graphical modelling. The analysis has shown that in its current state, the transportation network is insufficient and requires further expansion and modernization. The authors conclude that the capacities of Sabetta need to be supplemented with a modern network of railway, river and motor transport. This project may be expected to become a driver for regional development of the Urals and Siberia, create new jobs and attract foreign investment. The results of the study can be used for strategic planning of regional development of Russia's northern regions.
\end{abstract}

\section{KEYWORDS}

transnational transport corridor (TNC); transnational transport system; transport corridor; Arctic; Northern Sea Route (NSR), Sabetta sea port

\section{ACKNOWLEDGEMENTS}

The work is carried out based on the task on fulfillment of government contractual work in the field of scientific activities as a part of base portion of the state task of the Ministry of Education and Science of the Russian Federation to Ural State Forest Engineering University (the No. 26.8660.2017/8.9 "The Research Methodology of Forms of Economic and Technological Reality in the Aspect of Sustainable Forest Management"). Also it was did on the task on fulfillment of government contractual work in the field of scientific activities as a part of base portion of the state task of the Ministry of Education and Science of the Russian Federation to Perm National Research Polytechnic University (topic No. 26.6884.2017/8.9 "Sustainable development of urban areas and the improvement of the human environment").

\section{FOR CITATION}

Vukovic, N. A., Mingaleva, Zh. A., \& Mekhrentsev, A. V. (2019) Prospects of development of the transnational transport corridor of the northern sea route based on Sabetta sea port. R-economy, 5(1), 19-24. doi: $10.15826 /$ recon.2019.5.1.003

\section{Перспективы развития северного морского пути на базе морского порта Сабетта}

\author{
Н. А. Вукович ${ }^{1,3} \bowtie$, Ж. А. Мингалёва ${ }^{2}$, А. В. Мехренцев ${ }^{3}$, \\ ${ }^{1}$ Санкт-Петербургский государственный лесотехнический университет, Санкт-Петербург, Россия; \\ e-mail:shpak17121978@gmail.com \\ ${ }^{2}$ Пермский национальный исследовательский политехнический университет, Пермь, Россия \\ ${ }^{3}$ Уральский государственный лесотехнический университет, Екатеринбург, Россия
}

\section{АННОТАЦИЯ}

Северный морской путь (СМП) и его возможности для развития международных транспортных сетей широко обсуждаются не только в научной литературе, но и среди широкой общественности. Целью данной статьи является анализ экономических и логистических предпосылок для развития проекта, основанного на СМП, его возможностей и угроз в свете

\section{КЛЮЧЕВЫЕ СЛОВА}

международный транспортный коридор (МТК); международные транспортнологистические системы; транспортный коридор; Арктика; Северный морской путь; Сабетта 
регионального развития России. В статье также рассматривается потенциал морского порта Сабетта, который может быть превращен в транснациональный транспортный узел. Также обсуждается возможность развития интермодальных терминалов. Проект, представленный в этой статье, основан на мультимодальном транспортном подходе. Методологическая основа опирается на метод ветвей и графическое моделирование. Анализ показал, что в своем нынешнем состоянии транспортная сеть недостаточна и требует дальнейшего расширения и модернизации. Авторы приходят к выводу, что возможности Сабетты необходимо дополнить современной сетью железнодорожного, речного и автомобильного транспорта. Можно ожидать, что этот проект станет драйвером регионального развития Урала и Сибири, создания новых рабочих мест и привлечения иностранных инвестиций. Результаты исследования могут быть использованы для стратегического планирования регионального развития северных регионов России.

\section{БЛАГОДАРНОСТИ}

Работы выполняются на основании задания на выполнение государственных договорных работ в области научной деятельности в составе базовой части государственного задания Министерства образования и науки Российской Федерации для Уральского государственного лесотехнического университета (№ 26.8660.2017/8.9 «Методология исследования форм экономической и технологической реальности в аспекте устойчивого лесопользования»). Также было выполнено задание на выполнение государственной договорной работы в области научной деятельности в составе базовой части государственного задания Министерства образования и науки Российской Федерации в Пермский национальный исследовательский политехнический университет (тема № 26.6884.2017/8.9 «Устойчивое развитие городских территорий и улучшение среды обитания человека»).

\section{ДЛЯ ЦИТИРОВАНИЯ}

Vukovic, N. A., Mingaleva, Zh. A., \& Mekhrentsev, A. V. (2019) Prospects of development of the transnational transport corridor of the northern sea route based on Sabetha sea port. R-economy, 5(1), 19-24. doi: $10.15826 /$ recon.2019.5.1.003

\section{Introduction}

Efficient use of oceanic space is a complex problem, which cannot be addressed without a clear regulatory framework and state support.

For Russia, opening a new international transportation corridor via the Northern Sea Route (NSR) and the port of Sabetta (see Figure 1) presents a number of challenges, such as the lack of material resources (for example, food and construction materials) or the lack of transport connectivity in its northern regions. There is also a lack of developed internal water transport in the Urals and Siberia. Yet another problem is the low level of export and import activity in the Urals and the neighbouring regions.

\section{Literature review}

The prospects of the Northern Sea Route as an international transportation corridor, especially in connection with Sabetta Sea Port, are widely discussed nowadays. In this light, Sabetta is seen as the main driver for the development of the Arctic $[1-3]$.

There are numerous recent studies that point out the considerable prospects offered by the proj-

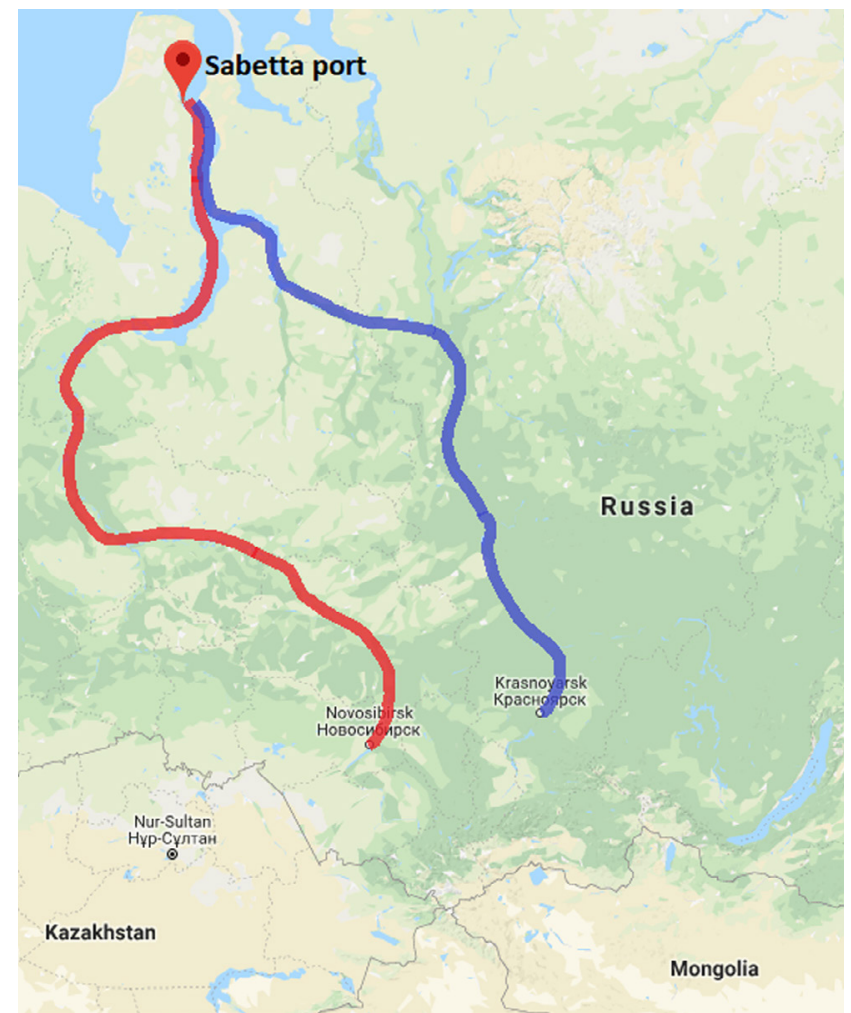

Figure 1. Model of the international transport corridor via the NSR and Sabetta

Source: authors (trajectory); Google Maps (map) 
ect [3-11]. Some studies described models for transit shipping along the NSR and made conclusions about the economic viability of this project $[8 ; 12 ; 13]$.

World history knows a lot of success stories, when simple towns due to their competitive advantages turned into international logistics hubs and started playing important roles in international economy, for example, Singapore and Dubai [14]. At the same time, despite the evident competitive advantages of the port, Sabetta project is still at its early development stage. In our opinion, the political factor impedes further progress of this project. According to Kozmenko, Selin, Salveliev, Stchegolkova, "development and utilization of the defensive potential by the Russian Federation in the Arctic is considered to be a forced response to potential threats and prevention of aggressive actions against the Russian Federation... substantial potential for conflicts is nested in the attempts of non-Arctic countries to get access to the resources of the North" [15].

This opinion is hard to disprove. However, we shall proceed from the premise that international economy will follow the course of sustainable development, and consider in this paper the economic component of the NSR's development.

\section{Methodology}

This research is aimed at optimizing the network model of the international transportation corridor via the NSR. The methodological framework used for this purpose includes the method of branches, arbitrary variation in network programming, and graphical modelling. Similar methodology was previously applied for the analysis of the NSR's potential for the development of the European North-East, and the northern Urals and the Komi Republic.

The goal of network programming in this research was to add new ribs to the model. The research focuses on the railroad network on the Yamal Peninsula linked to Sabetta (node 23 common drain). The common source in this model (node 22) is Moscow - Vladivostok railroad. The graph nodes represent the existing administrative centers of the Russian Federation (the list of nodes is presented in Table 1). The task for adding new ribs is a final unigraph, whose ribs and nodes have transit capacities and costs related to processing and transporting units of the flow:

$-\mathrm{V}$ - set of graph nodes ( $\mathrm{n}$ is the number of nodes);
- $\mathrm{U}$ - set of all graph ribs ( $\mathrm{K}$ is the number of ribs);

- $\mathrm{Ud}$ - set of possible new ribs ( $\mathrm{m}$ is the number of new ribs);

- Udi - is a set of new ribs incident to the $i$-th node;

$-+\mathrm{Ui}$ - set of ribs outgoing from the $i$-th node;

- -Ui - set of ribs incoming into the $i$-th node.

Table 1

Section of the railway line for the transnational transport corridor

\begin{tabular}{|c|c|c|c|}
\hline № & Node & Section of the railway line & Status \\
\hline \multirow[t]{2}{*}{1} & \multirow[t]{2}{*}{ Bovanenkovo } & Bovanenkovo - Karskaya & operational \\
\hline & & Bovanenkovo - Payuta & operational \\
\hline \multirow[t]{2}{*}{2} & \multirow[t]{2}{*}{ Pajuta } & Payuta - Novy Port & planned \\
\hline & & Payuta - st. Obskaya & operational \\
\hline \multirow[t]{3}{*}{3} & \multirow[t]{3}{*}{ st. Obskaya } & st. Obskaya -Vorkuta & operational \\
\hline & & st. Obskaya -Salekhard & $\begin{array}{l}\text { under con- } \\
\text { struction }\end{array}$ \\
\hline & & $\begin{array}{l}\text { st. Obskaya - Pol- } \\
\text { unochnaya }\end{array}$ & planned \\
\hline 4 & Vorkuta & Vorkuta - Moskow & operational \\
\hline 5 & Salekhard & Salekhard - Nadym & $\begin{array}{l}\text { under } \\
\text { construction }\end{array}$ \\
\hline 6 & Nadym & Nadym - Pangody & $\begin{array}{l}\text { under } \\
\text { construction }\end{array}$ \\
\hline 7 & Pangody & Pangody - Novy Urengoy & $\begin{array}{l}\text { under } \\
\text { construction }\end{array}$ \\
\hline \multirow[t]{2}{*}{8} & \multirow{2}{*}{$\begin{array}{l}\text { Novy Uren- } \\
\text { goy }\end{array}$} & Novy Urengoy - Yamburg & operational \\
\hline & & $\begin{array}{l}\text { Novy Urengoy - } \\
\text { Korotchaevo }\end{array}$ & $\begin{array}{l}\text { under } \\
\text { construction }\end{array}$ \\
\hline \multirow[t]{2}{*}{9} & \multirow[t]{2}{*}{ Korotchaevo } & Korotchaevo - Purpe & operational \\
\hline & & Korotchaevo - Igarka & planned \\
\hline 10 & Purpe & Purpe - Noyabrsk & operational \\
\hline 11 & Noyabrsk & Noyabrsk - Voynovka & operational \\
\hline 12 & Igarka & Igarka - Dudinka & planned \\
\hline 13 & Dudinka & Dudinka - Norilsk & operational \\
\hline 14 & Voynovka & Voynovka - Tyumen & operational \\
\hline 15 & Tyumen & & \\
\hline 16 & Karskaya & Karskaya - Harasavay & planned \\
\hline 17 & Novy Port & Ob Bay port & \\
\hline 18 & Harasavay & $\begin{array}{l}\text { NSR port in the Yamal } \\
\text { Peninsula }\end{array}$ & \\
\hline 19 & Norilsk & $\begin{array}{l}\text { final station in Kras- } \\
\text { noyarsk region via the port } \\
\text { of Dudinka }\end{array}$ & \\
\hline 20 & Yamburg & Ob Bay port & \\
\hline 21 & $\begin{array}{l}\text { Polunoch- } \\
\text { naya }\end{array}$ & $\begin{array}{l}\text { planned station in the } \\
\text { Khanty-Mansy Autono- } \\
\text { mous District }\end{array}$ & \\
\hline 22 & Istok & $\begin{array}{l}\text { Railway stations along } \\
\text { Moscow-Vladivostok line } \\
\text { (Novosibirsk, Omsk, Kras- } \\
\text { noyarsk, etc.) }\end{array}$ & operational \\
\hline 23 & Sabetta & Bovanenkovo - Sabetta & planned \\
\hline
\end{tabular}


The optimality criterion is the total cost of shipping goods within a fixed period of time. The costs include transportation costs, transit payments within the nodes, and the cost of creating new ribs.

\section{Model and results}

The resulting model for the key railroad routes connecting the Urals and Siberia with Sabetta and the NSR is based upon the analysis of the existing, designed, and planned railroads, the length of the railroads, and other factors (see Figure 2).

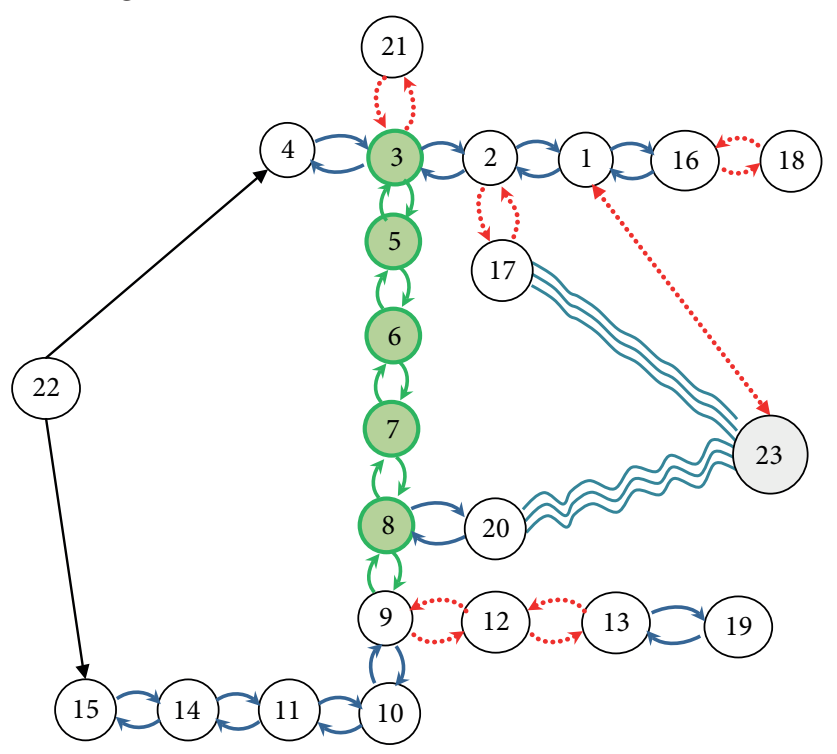

(9) Existing administration points and railway stations

(3) Existing administration points and railway stations under construction

Operating spur, branch, and main railway lines

Spur, branch, and main railway lines under construction

….... Planned spur, branch, and main railway lines

Maritime links between the ports in the Ob Bay

Figure 2. Graphical model of the main railway lines connecting the Urals and Siberia with Sabetta and the NSR

The nodes are listed in Table 1 in the methodology section.

Figure 2 illustrates that the existing administration points and railway stations under construction (p. $3,5,6,7,8)$ play the main role in hub development and are, therefore, crucial for investment and upgrading. Maritime links between the ports in the Ob Bay will provide this project with additional economic advantages and will be the driver for regional development.

\section{Graphical model of the key railroad links of the Urals and Siberia with Sabetta and the NSR}

Our net model of transportation between Ural and Siberian regions with Sabetta and the NSR has shown that for the moment Sabetta and the other Yamal peninsula ports are not directly connected by railroad with any central Russian regions. The only available railroad is Bovanenkovo - Vorkuta line (via Payuta and Obskaya stations). However, the capacity and length of this line are neither cost- nor time-efficient. This transportation corridor also leaves much to be desired in terms of cargo delivery time.

Commissioning of the railroad via Salekhard and Novy Urengoy (Obskaya station - Salekhard Nadym - Pangody - Novy Urengoy) would improve transport connectivity between the Urals and Siberia and Yamal seaports, which would also reduce the shipping costs and time.

Implementation of the multimodal approach would provide economic impulse for northern regions of the Urals and Siberia (Figure 3): new transportation infrastructure would stimulate construction projects in the connected regions, which would, in turn, create new jobs and industries there.

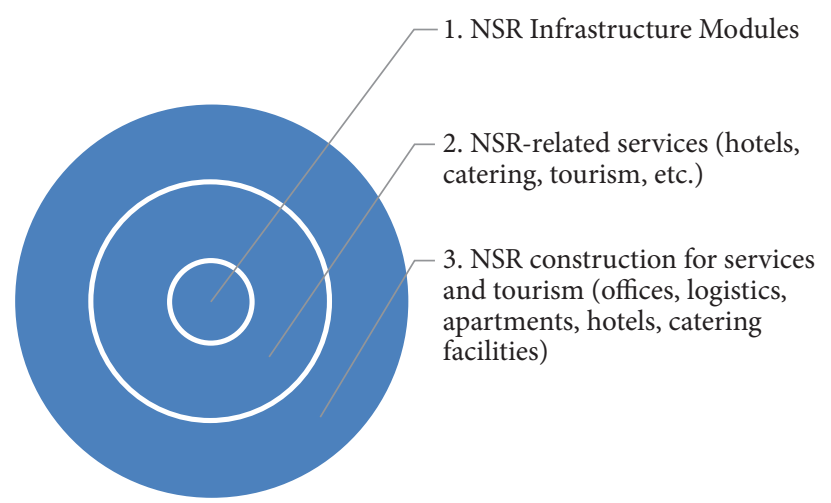

Figure 3. Model of regional development for Siberia and the Urals based on the NSR project

\section{Conclusion}

The international transport corridor via the NSR and Sabetta involves building a complex transportation network, which is allegedly going to include sea, river, railway and road transport.

Currently, sea ports of the Yamal peninsula have only one railway exit to the main routes via Vorkuta, which is obviously not enough for efficient cargo transportation. It is necessary to create 
a multimodal transportation hub in the Ob River region and supplement Sabetta's port capacities with railway, river, and automobile transport to enhance the efficiency of federal investment and establish a good foundation for new business projects, such as a free industrial and commercial economic zone. The NSR project is also likely to produce a considerable synergistic effect for regional development in remote areas of the Urals and Siberia.

\section{References}

1. Akimova, I. (2018, November). Northern Sea Route as the Main Driver for the Arctic Development: Challenges with Infrastructure and Opportunities for International Cooperation. In Abu Dhabi International Petroleum Exhibition \& Conference. Society of Petroleum Engineers.

2. Tabata, T., \& Tabata, S. (2018). Economic development of the Arctic regions of Russia. In Russia's Far North (pp. 11-26). Routledge.

3. Marchenko, N. (2014, June). Northern Sea Route: Modern State and Challenges. In ASME $201433^{\text {rd }}$ International Conference on Ocean, Offshore and Arctic Engineering (pp. V010T07A022V010T07A022). American Society of Mechanical Engineers.

4. Gritsenko, D., \& Efimova, E. (2017). Policy environment analysis for Arctic seaport development: the case of Sabetta (Russia). Polar Geography, 40(3), 186-207.

5. Goto, M. (2018). Cutting through channels: Local entrepreneurship of indigenous actors in Arctic Russia. In Russia's Far North (pp. 162-172). Routledge.

6. Dalaklis, D., Drewniak, M. L., \& Schröder-Hinrichs, J. U. (2018). Shipping operations support in the "High North": examining availability of icebreakers along the Northern Sea Route. WMU Journal of Maritime Affairs, 1-19.

7. Kaiser, B. A., Pahl, J., \& Horbel, C. (2018). Arctic Ports: Local Community Development Issues. In Arctic Marine Resource Governance and Development (pp. 185-217). Springer, Cham.

8. Milaković, A. S., Gunnarsson, B., Balmasov, S., Hong, S., Kim, K., Schütz, P., \& Ehlers, S. (2018). Current status and future operational models for transit shipping along the Northern Sea Route. Marine Policy, 94, 53-60.

9. Solvang, H. B., Karamperidis, S., Valantasis-Kanellos, N., \& Song, D. W. (2018). An exploratory study on the Northern Sea Route as an alternative shipping passage. Maritime Policy \& Management, 45(4), 495-513.

10. Pahl, J., \& Kaiser, B. A. (2018). Arctic Port Development. In Arctic Marine Resource Governance and Development (pp. 139-184). Springer, Cham.

11. Kelly, M. (2018). Seabird Distribution and Oil \& Gas Potential Along the Northern Sea Route, Russia: An Arctic Marine Conservation Case Study.

12. Afonin, A., Olkhovik, E., \& Tezikov, A. (2019). Conventional and Deep-Water Shipping Passages Along the Northern Sea Route. In Handbook of Research on International Collaboration, Economic Development, and Sustainability in the Arctic (pp. 314-337). IGI Global.

13. Kozmenko, S. Y., Masloboev, V. A., \& Matviishin, D. A. (2018). Justification of economic benefits of Artic LNG transportation by sea. Proceedings of the Mining Institute, 233. (In Russ.)

14. Akhavan, M. (2017). Evolution of Hub Port-Cities into Global Logistics Centres: Lessons from the Two Cases of Dubai and Singapore. International Journal of Transport Economics, 44(1).

15. Kozmenko, S. Yu., Selin, V. S., Saveliev A. N., \& Tschegolkova A.A. (2015). Nortern Sea Route: developing Arctic sea communications. Morskoy Sbornik, (8), 40-46. (In Russ.)

\section{Authors}

Natalya A. Vukovic - Associate professor, Saint-Petersburg State Forest Technical University (5 Instititsky per., Saint-Petersburg, 194021, Russia), Ural State Forest Engineering University (620032, 37 Sibirsky trakt, Ekaterinburg, Russia); e-mail: shpak17121978@gmail.com 
Zhanna A. Mingaleva - Professor, Perm National Research Polytechnic University (29 Komsomolsky pr., Perm, 614990, Russia)

Andrey V. Mekhrentsev - Professor, Ural State Forest Engineering University (37 Sibirsky trakt, Ekaterinburg, 620032, Russia)

ARTICLE INFO: received December 10, 2018; accepted March 18, 2019

\section{Информация об авторах}

Вукович Наталья Анатольевна - доцент, Санкт-Петербургский государственный лесотехнический университет (Россия, 194021, Санкт-Петербург, Институтский пер., 5), Уральский государственный лесотехнический университет (620032, Сибирский тракт, 37, Екатеринбург, Россия); e-mail: shpak17121978@gmail.com

Мингалева Жанна Аркадьевна - профессор, Пермский национальный исследовательский политехнический университет (Россия, 614990, Пермь, Комсомольский пр., 29)

Мехренцев Андрей Вениаминович - профессор, Уральский государственный лесотехнический университет (Россия, 620032, Екатеринбург, Сибирский тракт, 37)

ИНФОРМАЦИЯ О СТАТЬЕ: дата поступления 10 декабря 2018 г.; дата принятия к печати 18 марта 2019 г. 